\title{
The Myth of the New Man in Italian Fascist Ideology
}

\author{
Jorge Dagnino \\ Universidad de los Andes, Chile \\ dagninojorge@gmail.com
}

\begin{abstract}
This article addresses the key concept of the New Man within Fascist ideology, often considered as means and end of the Fascist revolution by the Fascists. Usually dismissed as an empty slogan by historians, it is argued in the following pages that the myth of the New Man is essential for a better understanding of the regime's totalitarian and revolutionary aspirations along with its quest of creating an alternative modernity and a post-liberal and post-socialist type of civilisation based on the primacy of the collectivity - a realm where Italians could realise their full potential as human beings.
\end{abstract}

\section{Keywords}

Italy - Fascism - ideology - myth - New Man

This article sets out to address, within the realm of the history of political ideologies, Fascism's attempt to refashion humankind. The central thesis is that the myth of the New Man can enhance our understanding of Fascism as a revolutionary and totalitarian experiment, along with its modern nature; that is, how Fascism, through this myth, sought the revolutionary and ultimate objective of commencing time anew, with the intent of creating a novel type of civilisation and human being based on the collectivity and the state. The myth of the New Man was a key feature in the ideological evolution of the Fascist movement and regime. Indeed, in an interview in late May 1924, Mussolini declared that

* Acknowledgment: The article forms part of my FONDECYT project N.3140039, Chile.

(C) DAGNINO, 2016 | DOI 10.1163/22116257-00502003

This is an open access article distributed under the terms of the Creative Commons Attribution-

Noncommercial 4.0 Unported (CC-BY-NC 4.0) License. http://creativecommons.org/licenses/by-nc/4,0/211:07:23AM 
Fascism represented 'the greatest endeavour in our history in making Italians' and this anthropological experiment was often presented as the means and end of the Fascist revolution. ${ }^{1}$

Beginning with an analysis of Fascism's perceptions and reconstructions of the experience of the Great War, this article moves on to address the Squadrist experience and argues that both of these historical processes were fundamental to the evolution of the myth of the New Man. Additionally, it will be demonstrated how the myth fuelled the expectations of many within the movement to achieve a new post-liberal and post-socialist type of civilisation, where Fascism was presented as the greatest experiment in history-making enterprises. Finally, the article re-visits the regime's anti-bourgeoisie and racial campaigns to consider how they were influenced by the utopian objective of refashioning Italians.

More often than not, Fascism's anthropological revolution has been seen through the sole lens of masculinity studies, often neglecting the wider implications of its ideological dimension. ${ }^{2}$ It has become commonplace to view Fascism as an expression of virility, to compensate for the perceived male anxieties at the turn of the twentieth century, provoked by the differing processes of modernisation that questioned the traditional structures of patriarchal society. Indeed, some scholars, such as Barbara Spackman have identified in virility the essence of Fascist ideology. ${ }^{3}$ Others like Christopher E. Forth and George L. Mosse, while acknowledging the importance of the subject and underscoring some of its central aspects, such as the glorification of the Great War and the cult of youth and action, nevertheless conclude that Fascism repeated, if in extreme forms, the normative ideals of masculinity within modern Western civilisation. ${ }^{4}$ Still others, like Sandro Bellassai, go a step further,

1 Benito Mussolini, Opera Omnia, vol. xx (Florence: La Fenice, 1963), 284 and, Partito Nazionale Fascista, Il cittadino soldato (Rome: Libreria dello Stato, 1936), 9-10. Although not the object of this article, mention should be made of Fascism's attempt to forge a New Woman, a being envisaged as a militant citizen who would defy the traditional notions of the presence of women in Italian society. The New Woman was supposed to go beyond the domestic sphere and to become a citizen mobilised for the totalitarian aspirations of the regime. See, for example, Helga Dittrich-Johansen, Le 'milite dell'idea' Storia delle organizzazionifemminili del Partito Nazionale Fascista (Turin: Leo S. Olschki, 2002).

2 Emilio Gentile's Fascismo: Storia e interpretazione (Roma and Bari: Laterza, 2002), 235-264, is an exception.

3 Barbara Spackman, Fascist Virilities: Rhetoric, Ideology and Social Fantasy in Italy (Minneapolis: University of Minnesota Press, 1996).

4 Christopher E. Forth, Masculinity in the Modern West: Gender, Civilization and the Body (Basingstoke: Palgrave Macmillan, 2008), 194-200; George L. Mosse, The Image of Man: The Creation of Modern Masculinity (Oxford: Oxford University Press, 1998), 155-180. 
proposing that the Fascist concept of masculinity was closely intertwined with an alleged anti-modernist discourse that supposedly characterised the Fascist regime. According to the Italian scholar, this anti-modernist outlook was manifested in the campaign against urbanisation, the exaltation of the peasant world, the critique of intellectuals and the anti-bourgeoisie campaign. ${ }^{5}$ Bellassai's analysis raises some criticism. Above all he displays a monolithic and one-dimensional vision of modernity, that is, the Enlightenment version of it. Instead, this article argues that there are a plurality of versions of modernity, Fascism being a form of alternative modernity. ${ }^{6}$ Furthermore, while it is true that some Fascist ideologues promoted the perceived values of the peasant world, frequently this was a recourse to a mythical past that acted as a springboard towards future-oriented cultural politics. The journal Il Selvaggio, for example, was the champion of the Strapaese [hyper province] movement and celebrated the myth of the good peasant and his virtues. However, the movement did not stand for a petty regionalism or a mere form of reactionary parochialism, and neither was it a purely aesthetic phenomenon or a little temple where one adores the past and takes refuge to hide from the realities and needs of the present'. Rather, it was an attempt to construct a specific Italian road to modernity, one that would avoid the pitfalls and anomies of the much-detested Western and liberal version of the concept, facilitating a Fascist conquest of modernity based on the primacy of the collectivity over the individual. ${ }^{7}$

With regard to Fascism's alleged critique of intellectuals, Bellassai tends to confuse it with the attack on anti-intellectualism. On the contrary, Mussolini's

5 See his following works: L'invenzione della virilità: Politica e immaginario maschile nel'Italia contemporánea (Rome: Carocci, 2011), 63-95; 'The Masculine Mystique: Antimodernism and Virility in Fascist Italy,' Journal of Modern Italian Studies 10 (2005): 314-335 and, La mascolinità contemporanea (Rome: Carocci, 2004), 76-98.

6 The subject of Fascism's relationship to modernity has been one of the most intensely debated in recent years. See, for example, Fernando Esposito, Fascism, Aviation and Mythical Modernity (Basingstoke: Palgrave Macmillan, 2015); Emilio Gentile, ed., Modernità totalitaria: Il fascismo italiano (Rome and Bari: Laterza, 2008); Roger Griffin, Modernism and Fascism: The Sense of a Beginning under Mussolini and Hitler (Basingstoke: Palgrave Macmillan, 2007); Ruth Ben-Ghiat, Fascist Modernities: Italy, 1922-1945 (Berkeley: University of California Press, 2001).

7 Orco Bisorco (Mino Maccari), 'Gazzetino ufficiale di Strapaese,' Il Selvaggio, 24 November 1927; Gioacchino Contri, 'Precisazione,' Il Selvaggio, 30 October 1930. On this important Fascist journal see Jorge Dagnino, 'Italianness during Fascism: The Case of Il Selvaggio,' Journal of Modern Italian Studies 19 (2014): 1-14; Walter L. Adamson, 'The Culture of Italian Fascism and the Fascist Crisis of Modernity: The Case of Il Selvaggio,'Journal of Contemporary History 30 (1995): $555^{-575}$. 
regime actively sought the consensus of intellectuals. ${ }^{8}$ What Fascists rejected was the type of liberal-democratic intellectual with his perceived detachment from 'life lived', as was the motto of the day. As Giovanni Gentile, one of the most distinguished philosophers of the period proclaimed, Fascism 'does not wage combat against intelligence, but rather against intellectualism, which is ... the malady of intelligence. ${ }^{9}$

Similarly, as will be shown, the anti-bourgeoisie campaign was not driven by an anti-modernist ethos but by a will to transcend individualism and atomism, with the end of creating a novel type of person and an anti-materialist revision of bourgeois liberal civilisation.

In sum, while masculinity studies are a valuable tool to study Fascism's quest to create a new kind of person, it is in the interaction of these with the ideological developments in Fascist Italy that the full implications of Fascism's anthropological revolution may be better understood. In this sense, in his ground-breaking monograph, Roger Griffin constructed an ideal-type of modernism as a 'revolt against decadence', in which the contemporary age was experienced, by a burgeoning number of artists, writers, politicians and intellectuals, since roughly the second half of the nineteenth century, as an epoch of involution and regression in terms of the loss of beauty, meaning and spiritual and physical health. The effect of Western modernisation produced a variety of palingenetic reactions that sought to establish a healthier social and moral basis for society and to produce a new kind of man. For Griffin, the common denominator of modernist movements, whether from right or leftist origins, lay in the aim of fostering a sense of meaning and transcendent value to countervail the secularising and disembedding forces of modernisation. ${ }^{10}$ Even though the British academic does not treat the subject of the New Man in great detail, his ideal type of modernism offers an excellent starting point for this article.

\section{The Legacy of the Great War and Squadrismo}

Following the Risorgimento, the intellectual, political and cultural elites were convinced of the momentous need to refashion the populace and redeem

8 Alexander J. Gregor, Mussolini's Intellectuals: Fascist Social and Political Thought (New Jersey: Princeton University Press, 2005).

9 Giovanni Gentile, Che cosa è il fascismo: Discorsi e polemiche (Florence: Vallecchi, 1925), 98.

10 Griffin, Modernism and Fascism, 49-55, 116-117. 
it from the perceived and almost atavistic vices and degenerations, which affected the moral and civic conscience of Italians, and were impeding the nation's achievement of modernity. Hence, the need to forge a new Italian capable of challenging and facing up to the demands of modern life."

During the Great War, the theme acquired a more burning currency. The all-encompassing characteristics of the conflict constituted, for many future Fascists, the first therapeutic and regenerative experiment in the nationalisation of the masses in the short history of the peninsula. Among the most committed Fascists, the war was perceived and represented as the dawn of a new era, the acceleration of historical time, the profound transformation of the ambit of mentalities and, more generally, of the mental landscape of those who partook in the conflict. For Giovanni Gentile, the First World War had been a solution to 'a profound spiritual crisis' affecting the nation, while for the veteran Angelo Amico the conflict had brought about the 'spiritual unity' of the populace, in what was portrayed as the greatest nation-making enterprises realised by Italians until that point. ${ }^{12}$

The Great War was also depicted as a future-oriented event, through which the remnants of the old and liberal Italy had been definitively removed from the hearts of true Italians. It had forever cut off the nation from a 'conventional and artificial spiritual world' and had given citizens the sense of delivering youthful and unprejudiced spiritual values, while at the same time forging New Men. These New Men had learnt in the trenches to fortify their characters and wills, and had been able to radically replace, once the war was over, old institutions, ideas, values and systems of hierarchy. ${ }^{13}$ The conflict had been a tremendously powerful palingenetic endeavour, which had finally cemented the peninsula as a powerful nation, uniting its citizens around a common passion, thought, hope and destiny. It had given the nation a true character, enabling it to contribute to history-making. The Great War had 'given back to man his dignity' and unfettered his inner nature after decades of rampant liberal materialism, transforming him into a dominator and not a serf to sheer force. He was a new type of human being, a creator of history,

11 Emilio Gentile, La Grande Italia: Il mito della nazione nel XX secolo (Rome and Bari: Laterza, 2006), 35-41.

12 Giovanni Gentile, 'L'essenza del Fascismo,' in La civiltà fascista, ed. Giuseppe L. Pomba (Turin: Editrice Torinese, 1928), 97; Angelo Amico, Combattentismo e fascismo (Milan: Corbaccio, 1932), 19.

13 Bruno Spampanato, Democrazia fascista (Rome: Politica Nuova, 1933), 167; Camillo Pellizzi, Problemi e realtà del fascismo (Florence: Vallecchi, 1924), 82. 
endowed with a will of power, justice and good. In summary, the humble soldier of the trenches had realized the ideal of the 'revolutionary of Mazzini and Nietzsche's superman'.14

For the Duce himself, the war had seen the emergence of a true and proper 'trenchocracy'. Its members were the aristocrats of the future, destined to subvert the existing political, social and cultural order, who with 'passion, faith and tenacity' would engage in the building of a new body politic and transform men into conscious citizens. ${ }^{15}$ Furthermore, the conflict had purportedly produced a dramatic anthropological division among Italians, between the interventionists and the neutralists. Men had had to face, according to Fascist propaganda, an extreme choice between heroism and cowardice, idealism and selfishness, between the 'instinct of spiritually projecting life beyond matter and the brutal instinct of animal conservation.16 Only the interventionist was a true and virile man, whereas the neutralists were often portrayed as lacking masculinity and the attributes of manhood, such as courage, heroism, stamina in the face of mortal danger and a religious sense of the fatherland. Indeed, for Mussolini the war had seen the soldiers acquire a larger mental landscape and an enhanced spirituality, witnessing the titanic struggle between 'Man and the anti-Man.' ${ }^{17}$ The tendency to deprive those who had opposed the war effort of their human nature was closely intertwined with the perception that the conflict has masculinised and revitalised the country. For the future Fascist hierarch, Giuseppe Bottai, himself a volunteer during the Great War, the confrontation had created a revolutionary man, endowed with a new morality and destined to subvert the existing establishment. The soldier of the trenches had become a 'man among men', in possession of a 'youthful masculinity' who had returned to Italy transformed, to a country where there 'had remained nothing but effeminate and old people.18

14 Partito Nazionale Fascista, La dottrina del fascismo (Rome: Libreria dello Stato, 1936), 26-27.

15 Benito Mussolini, Opera Omnia, vol. x, 140-141. The article 'Trincerocrazia' was first published in Il Popolo d'Italia on 15 December 1917. For the myth and cult of the Duce as the embodiment of the New Man see, for example, Stephen Gundle, Christopher Duggan and, Giuliana Peri, ed., The Cult of the Duce: Mussolini and the Italians (Manchester and New York: Manchester University Press, 2013); Didier Musiedlak, Il mito di Mussolini (Florence: Le Lettere, 2009) and, Luisa Passerini, Mussolini immaginario (Rome and Bari: Laterza, 1991).

16 Mario Carli, L'Italiano di Mussolini (Verona: Mondadori, 1930), 56.

17 Benito Mussolini, Scritti e discorsi (Milan: Hoepli, 1933-1939), 12 vols., here vol. IV, 363-364.

18 Giuseppe Bottai, Pagine di Critica Fascista (Florence: Le Monnier, 1942), 9 and 14. 
When the Fascist movement was formed in March 1919, many of its adherents sought to prolong and further the new values gained in the war. This coincided with the creation of the paramilitary formations of Fascism, Squadrismo, which was the first indication of Fascism's intent to militarise politics. ${ }^{19}$ The experience of fighting for a squad was perceived by many of its members as a dramatic, life-changing and redeeming experience, particularly for those who were too young to have participated in the First World War. For the hierarch of Cremona, Roberto Farinacci, Squadrismo had the daunting task of transforming the 'national psyche' and was depicted as the soul of every genuine Fascist who represented the 'abyss which separates us from the old Italy'. ${ }^{20}$ For others, like Luigi Fontanelli, Squadrismo had constituted the 'passage to life, to the true life, to life as a permanent activism determined by our will. ${ }^{21}$ For many, the combat of the paramilitary formations was an expression of heroism and beauty in a disenchanted world embodied by the liberal-bourgeois order and world vision. Thus, the duty of every squad member was, in the midst of a perceived liminoidal world, to endow it with beauty, youthfulness, heroism and donation of the self for the envisioned national totalitarian community. In an age where personal and national identities were perceived as extremely fragile, Squadrismo offered an image of certainty and a possibility of the very modern notion of the development of the self. The leader of Fascism in Ferrara, Italo Balbo, for example, wrote that the fighting had transformed the character of the young activists, rendering them bolder, temerarious, open-minded and enveloped in a spirit of 'chivalry not devoid of gaiety.' ${ }^{2}$

In the mindset of the Squadrists, the image of death played a crucial role, not only as an expression of the sacralisation of politics, with its rituals, ceremonies and symbols, but also in terms of the development of manhood. To die in a punitive expedition was frequently characterised as a 're-consecration

19 On Squadrismo see, for example, Matteo Millan, Squadrismo e squadristi nella dittatura fascista (Rome: Viella, 2014); Sven Reichardt, Camicie nere, camicie brune: Milizie fasciste in Italia e in Germania (Bologna: Il Mulino, 2009); Mimmo Franzinelli, Squadristi: Protagonisti e tecniche della violenza fascista, 1919-1922 (Milan: Mondadori, 2004); Roberta Suzzi Valli, 'The Myth of Squadrismo in the Fascist Regime,' Journal of Contemporary History 35 (2000): 131-150.

20 Roberto Farinacci, Andante mosso, 1924-1925 (Milan: Mondadori, 1929), 197-198; Roberto Farinacci, Un periodo aureo del partito nazionale fascista (Foligno: Franco Campitelli, 1927), 295 .

21 Luigi Fontanelli, Sentimento della rivoluzione (Rome: Unione Editrice Sindacale Italiana, 1941), 129.

Italo Balbo, Diario 1922 (Milan: Mondadori, 1932), 10. 
of man's dignity and one's nobility as Italian., ${ }^{23}$ It was indeed the means of violence that heightened this identification of Italianness with a complete manhood. In this sense, it is no wonder that many Fascists celebrated the alleged 'virtues' of violence, particularly its sacral and aesthetic features. For Mino Maccari, violence should be refined, according to the principles of good taste and elegance. Moreover, for the Tuscan artist and intellectual, 'violence is the voice of God. Violence is the justice of nature. Violence is the indispensable weapon of the daily civil struggle'. He also depicted it as the 'noblest weapon, the purest ... and most Christian in every battle', an essential tool in the formation of a strong character. ${ }^{24}$

In sum, the cult of Squadrismo reflected the tendency of many Fascists to consider the revolution as an embryonic totalitarian experiment and a self-understanding of the movement characterised by a sense of speed, selflessness, creative aggressiveness, initiative, fulfillment and boldness.

\section{Forging Historical Agents for the Stato Nuovo}

As a political and revolutionary movement, Fascism had emerged as a reaction and revision of the rationalistic and teleological underpinning of liberal and socialist visions of history and politics, and of the place of men within them. They were presented by Fascist ideologues as out-dated forms of political organisation and historical representation, which in the midst of the civilisational crisis that had arisen with the Great War, were unable to render justice to the complexities and fluidity of modern life. In particular, they were criticised for leaving the masses devoid of a sense of political and existential belonging and for being trapped in rigid and pre-conceived ideological formulae. Liberals and socialists had become prisoners of their own ideologies and estranged themselves from the dynamism of life. Politics after all, from the perspective of many within the movement, was a 'mirror of life, which is novelty, creativity and the unexpected', traits that could not be comprehended using the lens of the old ideologies. ${ }^{25}$ Moreover, liberalism and socialism were charged for being passive and naïve conceptions of the world and of history. Fascism denied the existence of an 'end' or final 'goal' to be achieved in history. There was no such

\footnotetext{
23 Camillo Pellizzi, Problemi, 101.

24 Mino Maccari, 'Parla Il Selvaggio,' Il Selvaggio, 28 September 1924; Sugo-Di-Bosco, 'Parla Il Selvaggio,' Il Selvaggio, 18 May 1925. Sugo-Di-Bosco was one of the pseudonyms used by Maccari.

25 Bruno Spampanato, Popolo e Regime (Bologna: Cappelli, 1932), 42-43.
} 
thing as a 'rational' course in history. Nor were absolute values to be pursued within the unfolding of history, whether it be the terrestrial proletariat paradise, humanitarianism, pacifism, rights of men and of the individual, among others. ${ }^{26}$ Indeed, history belonged to those capable of making it, as an expression of willfulness, force and activism. Moreover, for some Fascists the will was a quintessentially male faculty, whereas nature was fundamentally feminine and passive and destined to be 'fertilised' by the will. ${ }^{27}$

The main characteristic of the history-maker was the journey from being 'a spectator to an actor in the history of the nation' and a 'builder of the future.'. 28 If modern man were to meet the challenges of the day, he had to realise that the world into which he was born was there to be radically transformed. By subjecting it to his will he would make it his instrument by spiritualising it. In this sense, Fascism had arisen as 'the ideal of the youth of Italy', which voiced 'the rebellion of the spirit against a suffocating materialism. ${ }^{29}$

In history-making, men could realise their full potential using a combination of activism and voluntarism that rendered justice to the sought after qualities of the new Italian. This perspective, of course, derived much from Fascism's conception of life. Life was above all a continuous struggle and combat in a risky world that required courage and tenacity. Above all, this activistic and heroic vision of life manifested itself in not resigning oneself to a fatalistic destiny, but rather in defying it, overcoming it and 'forging a better one ... so as to re-commence life', in a true modernist spirit. ${ }^{30}$ Through Fascism, for the first time in the history of the young nation the masses were entering into the categories of time and space, a new qualitative and existential experience, as the prominent ideologue Paolo Orano was quick to point out. ${ }^{31}$ Fascism was, furthermore, often portrayed as an accelerator of historical and psychological time, imposing a new rhythm to the lives of ordinary Italians, to shatter the vain and easy formulae of the past, animated by a 'will to annul at

26 For Fascist visions of history see, Claudio Fogu, The Historic Imaginary: Politics of History in Fascist Italy (Toronto: University of Toronto Press, 2003); Pier Giorgio Zunino, L'ideologia del fascism: Miti, credenze e valori nella stabilizzazione del regime (Bologna: Il Mulino, 1995).

27 Edgardo Sulis, Imitazione di Mussolini (Milan: Novecentesca, 1934), 60.

28 Bruno Spampanato, Discorsi al Popolo (Naples: Alberto Morano, 1932), 20; Augusto Turati, Una rivoluzione e un capo (Rome and Milan: Libreria del Littorio, 1927), 169.

29 Pietro Gorgolini, The Fascist Movement in Italian Life (Boston: Little, Brown \& Company, 1923), 84 .

$30 \quad$ Mussolini, Scritti e Discorsi, vol. IV, 284.

31 Paolo Orano, Il Fascismo: Rivoluzione delle camicie nere, lo stato totalitario (Rome: Pinciana, 1940), 103. 
all costs in us the vestiges of the past, so as to live only in the future. ${ }^{32}$ Moreover, this futural thrust present in Fascist ideology entailed an integral and totalitarian conception of politics, in the sense that politics was the ultimate construction by men that 'could not distinguish itself from ethics, religion or any other conception of life' and which enveloped men's will, thoughts and sentiments. ${ }^{33}$

One of the most grandiose history-making enterprises that Fascism set out to realise was the manufacture of a new kind of man. As Mussolini solemnly proclaimed toward the end of October 1926, the quest in this ambit was to 'render unrecognisable both spiritually and physically the face of the nation' within ten years and to create the 'new Italian' who would not resemble the one of the past. ${ }^{34}$ It was necessary to create a new mentality and thought for the Italian of tomorrow, who was depicted as a cognitively different type of human being. This very ambitious totalitarian and utopian project entailed the creation of a 'totally new human figure, an inedited model of Italian virility ... a modern man wholly directed towards the future', a new man from head to toe, in his conscience, feelings and will. ${ }^{35}$

These new Italians would constitute the novel aristocracy of tomorrow, an aristocracy characterised not solely for its faith, devotion, strength and discipline, but also for its historical sense of responsibility and authority. The latter was portrayed not as a mere positive law or constitutional system, but as the principle born from a 'creative action' which gave the state its dynamism and ethical character. In this regard, Fascism was not solely a physical force but a mystical one of 'internal elevation and liberation' ${ }^{36}$ This spiritual tendency can be further grasped by understanding the Fascist notion of freedom and its mission of rescuing man from materialism, secularism, sheer individualism, and other disembedding forces of Western modernisation. True liberty, according to many theoreticians was, unlike the conception of classic liberalism, not a right but a duty and an intimate conquest of the self. Likewise, it did not deterministically entail equality among individuals but a sense of privilege and hierarchy of values. As Camillo Pellizzi eloquently wrote, man was not destined to be an egotistical and selfish individual but rather 'to liberate man is to render him more of a man, a human being as a historically concrete entity, continuously self-made and historicised in an ever-deepening spiritual

32 Augusto Turati, Ragioni ideali di vita fascista (Rome: Giorgio Berlutti Editore, 1926), 62-63.

33 Gentile, 'L'essenza del Fascismo', 109-110.

34 Mussolini, Opera Omnia, vol. xxıI, 246.

35 Carli, L'Italiano di Mussolini, 42 and 98.

36 Pellizzi, Problemi, 104. 
process. ${ }^{37}$ Moreover, Fascists such as Giovanni Gentile strongly believed that Fascism had resolved the apparent contradiction between authority and liberty, 'indeed, Fascism does not oppose liberalism as the system of authority against the system of liberty, but as the system of the true and concrete liberty against the notion of an abstract and false freedom. ${ }^{38}$ In the philosopher's mind, it was the state that bestowed men with a concrete, dynamic and 'real' freedom. Indeed, in the depths of his self, man was identified with the will of the state and in this will resolved every religious and moral concern or, in other words, the state was actuated in the same conscience and will as the individual historical subject.

The Ethical State advocated by Giovanni Gentile and other prominent Fascists was the quintessential history-maker entity. Furthermore, the state, as conceived by the Italian philosopher, was a totalitarian, moral and religious manifestation, a concrete and historically determinate actuation of a universal will, in which the individual, through sacrifice and abnegation, realised his selfhood. For Gentile, 'the maximum of freedom coincides with the greatest force of the state'. In this sense, the ideal New Man was one who 'felt in his heart the pulsation of the supreme interest of the community and the sovereign will of the state. ${ }^{39}$

In fact, the New Man envisioned by the Fascists was a collectively organised human being. After all, the initial decades of the twentieth century had seen, from the perspective of Fascism, the emergence of a new type of civilisation, distinguished by its 'new spiritualism' and 'great sense of the collective', for the birth of the masses and its dynamic new order, rendering possible the creation of the 'complete man', who no longer was at war in the struggle for life, but was a disciplined, 'aware and active participant in the common solidarity of the nation'. ${ }^{40}$ Moreover, the New Man advanced by Fascism, in addition to being a collectively organised human being, was able to reach an intra-mundane transcendence in the realm of the national totalitarian community. This was, according to a popular interwar volume, a 'heroic conception, because the true hero is he who affirms, in the sacrifice of his own person, his strong will to endure beyond the limits of his corporeal existence.41 The defiance of time implicit in Fascism's anthropological revolution involved a religious and, more broadly, a spiritual ideological substrate in this totalitarian endeavour. These

$37 \quad$ Ibid, 129.

38 Gentile, 'L'Essenza del Fascismo', 116.

39 Gentile, Che cosa è il fascismo, 50, $5^{2}$.

40 Augusto De Marsanich, Civiltà di masse (Florence: Vallecchi, 1940), 12, 15, 37.

41 Partito Nazionale Fascista, Il cittadino soldato, 28-29. 
features are perhaps better understood if we turn to the text Dottrina del Fascismo, co-written by Mussolini and Giovanni Gentile and originally published in 1932. According to the authors, the Fascist man was an individual historical subject solely in the sense that he was 'nation... moral law that brings together individuals and generations in a tradition and mission ... to build through duty a superior life, free from the constraints of time and space'. In this quest for an immanent transcendence lay Fascist spirituality and thus, the true value of man, who was aware of the difficulties of modern life and ready to overcome them to conquer his interiority and develop his self. ${ }^{42}$

Similarly, Giuseppe Bottai called for a modern and Fascist humanism, which would avoid the errors of liberal individualism and the abstract universalism of socialism. Like Mussolini's and Gentile's visions, Bottai's portrayal of a new humanism betrayed a totalitarian conception of life and politics. For the hierarch, the New Man of Fascism was an integral man, in the family ... in the nation, in the state ... the Fascist man is wholly oriented towards totality, he remounts from his own particularity towards the unity of the state, and in this ... he acquires the awareness of himself and of his personality' ${ }^{43}$ As such, Fascism was much more than a social or political revolution. It was, above all, a 'revolution of the human spirit' that conceived the state not as an entity that mortified men, but one that made him more manly, so that his conscience itself felt the demands of the community. For Bottai, the myth of the New Man was a most potent one, capable of 'transforming us internally, renewing us in our depths and making us to be reborn to a new life', in order to establish the primacy of man over matter and institutions. ${ }^{44}$

Along similar lines, the Fascist university student Arnaldo Di Nardi, spoke of the 'integral man' and of Fascism as the 'restoration of man in his necessary and eternal unity', leaving behind decades if not centuries of partial visions of humankind that had fragmented man at his inner core and unity of life. ${ }^{45}$ This integral conception of manhood was manifested in the 'triumph of man who overcomes himself as individual and is capable of giving himself a norm'. Furthermore, the integral New Man, realising his selfhood within the totalitarian state was a 'politician, an economist, a religious, saintly and warrior man'46

The New Man had to build, discipline and conquer his spiritual personality. The control of one's instincts and passions was, for many Fascists, the gateway

42 Mussolini, Scritti e Discorsi, vol. viII, 68-69.

43 Giuseppe Bottai, 'Appelli all'uomo,' Critica Fascista, 1 January 1934.

44 Giuseppe Bottai, 'La giovinezza come ordine nuovo,' Primato, 15 July 1942.

45 Arnaldo Di Nardi, 'L'unità dell'uomo,' Roma fascista, 28 July 1938.

46 E. Gropallo, 'Il Partito e la sua legge,' Il Campano, April 1935. 
to a morally and spiritually reinvigorated nation and man. The intimate possession of the self was the prerequisite for all other victories, whether in the military, political, cultural or social realm. Indeed, the entire Fascist revolution was equated to the creation of New Men as the embodiment of a new civilisation. Were it not to succeed in this pursuit, the entire revolutionary potential of Fascism would evaporate and ultimately fail. ${ }^{47}$

\section{The New Man during the years of Totalitarian Radicalisation}

The aim to refashion Italians received further momentum during the 1930s, especially after the invasion of Ethiopia in 1935 and the ensuing proclamation of the Fascist Empire in May 1936. Above all, during this period, the Fascist National Party, under the leadership of Achille Starace, notably extended its sphere of influence in Italian politics and society. In 1937, with the creation of the Gioventù Italiana del Littorio, the party acquired a near monopoly on the formation of the nation's youth. Furthermore, the party extended its efforts to increase the fascistisation of the country, and led the battle for the change of customs, ethics and mentalities among the population, to render them worthy members of a martial nation. The new Italian, during this phase of national history, should above all be distinguished for his frankness, courage, discipline, obedience, sacrifice and readiness to resort to violence. Life itself was a permanent war and had to be combated with the disciplined spirit of a soldier, removing any trace of compassion that could weaken the nation's might. The Duce, in a speech of 1938 declared that he was convinced that only war and a militaristic education could remove the flaws of the 'old' man and old Italy, such as scepticism, indifference, disorder and corruption, defects encapsulated in the stereotype of the mandolinistic Italian. Furthermore, Fascism had the task of creating a militaristic atmosphere where Italians could take pride in knowing that they were permanently being mobilised. ${ }^{48}$

During the 1930s, it was emphasised that the Italian male should abhor every frivolity and relaxation of morals. It was frequently commented that his 'beauty lays in his roughness and his elegance in the perfect dominion of his muscles' while Fascism was 'virility and simplicity. Not frivolity or vanity, not femininity, but an understanding that to live is to have a serene simplicity made of force and internal severity'. 49

Edgardo Sulis, Rivoluzione Ideale (Florence: Vallecchi, 1939), 33.

48 Mussolini, Opera Omnia, vol. xxIv, 117.

49 Signifier, 'Combattere il "gagaismo"', Gioventù fascista, 15 July 1933. 
To ensure the radicalisation and ultimate completion of the anthropological revolution, Fascists thought it necessary to remove their opponents, as far as possible, from the national arena, whether it be for reasons of politics, race or gender. The driving force behind this palingenetic and ultimately utopian enterprise was the dream of fashioning a homogeneous and martial totalitarian community, purifying the nation of perceived deleterious elements.

In this sense, one can further grasp the obsession and bitterness of the anti-bourgeoisie and racial campaigns introduced by the Fascists in the late 1930s. Above all, these were directed towards the elimination of every residue of the liberal-bourgeois culture and civilisation, which were supposedly impeding the realisation of the Fascist revolution. The bourgeoisie was used as a political myth to designate everything and everyone who did not correspond to Fascism's totalitarian morality, particularly to its ideal of a New Man and his alleged attributes of heroism, selflessness, purity, creative aggressiveness, love for the fatherland and firm moral coherence in thought and practice. In a semi-secret speech to the Grand Council of the party in late October 1938, Mussolini himself identified the bourgeoisie as the number one enemy of the revolution. More than a strict and well-defined economic category, the Duce referred to the bourgeoisie as a moral notion, a state of mind and temperament, which was in stark contrast with the Fascist mentality. The bourgeois was portrayed as a sedentary, pessimistic, pacifistic, merciful, sentimental and uncreative individual. Mussolini concluded his speech by declaring that 'this bourgeois spirit ... must be isolated and destroyed'. During the Second World War, according to Galeazzo Ciano, the leader of the Fascist regime would go as far as to speak of the need to 'physically destroy' the bourgeoisie. ${ }^{50}$ Furthermore, trapped in an egotistical and selfish materialistic individualism, the bourgeois was a homeless mind, deprived of the qualities needed to render him a true historical agent in the extraordinary times that were taking place under Fascism. A new self-awareness was demanded, one that would do justice to a Fascist people that had come to terms with its historical task of refashioning its populace and exerting its influence in its new African Empire. Moreover, the bourgeois spirit was depicted as passive and feminine while the

50 Mussolini, Opera Omnia, vol. XxIX, 187-192; Galeazzo Ciano, Diario 1937-1943 (Milan: Rizzoli, 1980), entry for 12 August 1940. For the anti-bourgeoisie campaign see, for example, Thomas Buzzegoli, La polemica antiborghese nel fascismo (1937-1939) (Rome: Aracne, 2007); Paolo Buchignani, La rivoluzione in camicia near: Dalle origini al 25 Luglio 1943 (Milan: Mondadori, 2006), 311-328; Domenico Settembrini, Storia dell'idea antiborghese in Italia, 1860-1989 (Rome and Bari: Laterza, 1991), 277-354. 
Fascist was the active, history-maker and virile principle governing the modern world. ${ }^{51}$

Although Fascism had always presented an anti-bourgeois component in its ideology, it was during the 1937-40 period that it really acquired a sense of urgency. Many factors contributed to this radicalisation, including the proclamation of the Empire in May 1936, the Spanish Civil War, the ever-closer relationship with Nazi Germany and the zealous leadership of the party provided by Achille Starace. Above all, there was Mussolini's hubristic belief and conviction of the need to render Italy a warrior nation capable of meeting the challenges of its Imperial destiny and vocation.

In a popular volume on the subject, Salvatore Gatto wrote of how the Fascist revolution was in essence the negation and final overcoming of the bourgeoisie and how the latter was a pernicious attitude of the spirit and way of life. It did not share central tenets of the Fascist totalitarian morality, such as the cult of speed, youth and dynamism, the belief in the sanctity of heroism and the warrior mentality. In a nutshell, Fascism stood for a 'tough life, danger, selflessness and sacrifice', whereas the bourgeois was the quintessential 'antirevolutionary' ${ }^{2}$ Furthermore, in the Fascist imaginary the bourgeois was often conceived as an individual who saw in money the measure of every man, neglecting and disbelieving in the force of the spirit and of the will. A hedonistic human, he was devoid of creative and galvanising myths, ideals and spiritual beliefs. He was, moreover, depicted as a cosmopolitan and without national roots. In this sense, he was an artificial and inferior human being, incapable of developing an 'authentic personality'.53 The bourgeois was, additionally, often presented as a coward and a lover of peace at all costs, an adipose man who refrained from an active and sporty life, as he lacked energy, audacity and willpower. A lover of appearances and status-seeker, he worshipped material goods above all. He was also an opportunist who hated the military spirit and thus lived in a spiritual and bodily drowsiness. He was in a permanent state of 'moral and physical depression'. ${ }^{4} \mathrm{~A}$ monotonous and colourless individual, the bourgeois was above all an inferior being, an incomplete man and effeminate snob. He had no right to be a citizen of the totalitarian state as he was a

$5^{1} \quad$ Pier Luigi Trolli, 'Personalità liberale e personalità fascista,' Dottrina Fascista, December 1937; F.A. Spinelli, 'I borghesi fascisti,' Libro e Moschetto, 21 January 1939.

$5^{2}$ Salvatore Gatto, Il Borghese (Varese: La Tipografica Varese, 1941), 19-21. Also see Partito Nazionale Fascista, Il primo e secondo libro del fascista (Rome: Mondadori, 1941), 90.

53 Fontanelli, Sentimento, 80.

54 Gatto, Il Borghese, 39. 
'failed and spurious man'. ${ }^{55}$ The bourgeois was a man of order, not a revolutionary, a being who lacked a true sense of Fascist masculinity and virility. Indeed, according to Salvatore Gatto, the bourgeois was essentially a 'hermaphrodite' and, thus a 'degenerate'. Furthermore, the bourgeois was a handicapped individual, a 'paralytic and arteriosclerotic', utterly unable to participate in the grandiose history-making enterprises of the regime. ${ }^{56}$ Such was the threat imposed by this imaginary bourgeois, that the revolution, were pedagogical and cultural remedies to fail in the eradication of this 'tumor', would have to recur to 'exceptional remedies, more radical and persuasive' as Roberto Pavese menacingly warned. ${ }^{57}$

The African colonial enterprise had raised among many Fascists the issue of safeguarding the alleged purity of the Italian race against inferior ones, to maintain the 'colonising superiority', expressed in Fascist New Men who were purportedly dominators and conquerors above all. ${ }^{58}$ For Luigi Fontanelli, the racial question stood at the root of all problems and with it Fascism acquired a deeper sense of its mission, in the sense that it inaugurated a new era of greatness and power for the projected Fascist ideal of a new civilisation. Indeed, for Fontanelli the racial campaign was the qualitative phase of the demographic battle to improve the moral, spiritual and physical characteristics of the Italian people. Moreover, he warned against the temptation of reducing racial thought and practices to sheer anti-Semitism. ${ }^{59}$ Fascist racial policy was not solely a negative project, but a modern pursuit for a racial and 'spiritual' homogeneity and the construction of a 'balanced' social order, a 'rational' biological and socio-political arrangement that would fortify Italy's imperial destiny and its character as a warrior nation. ${ }^{60}$ Furthermore, Fascist racism, in its quest to

55 Orano, Il Fascismo, 421.

56 Gatto, Il Borghese, 39, 35, 69.

57 Roberto Pavese, 'Bonifica antiborghese,' in Processo alla borghesia, ed. Edgardo Sulis (Rome: Edizioni Roma, 1939), 69.

58 Vincenzo Mazzei, Razza e Nazione (Rome: Ed. Italiane, 1942), 64. There is a burgeoning literature on Fascist racial policies. See, for example, Gaia Giuliani and Cristina LombardiDiop, Bianco e Nero: Storia dell'identità razziale degli italiani (Milan: Le Monnier, 2013); Francesco Germinario, Fascismo e antisemitismo: Progetto razziale e ideologia totalitaria (Rome and Bari: Laterza, 2009); Francesco Cassata, 'La Difesa della Razza': Politica, ideologia e immagine del razzismo fascista (Turin: Einaudi, 2008); Marie-Anne Matard-Bonucci, L'Italia fascista e la persecuzione degli ebrei (Bologna: Il Mulino, 2008); Aaron Gillette, Racial Theories in Fascist Italy (London and New York: Routledge, 2002).

59 Fontanelli, Sentimento, 70-71, 92.

6o Carlo Cecchelli, 'Origini ed omogeneità della razza,' in Inchiesta sulla razza, ed. Paolo Orano (Rome: Pinciana, 1939), 71-8o. 
unite people, state and Duce was for many the ultimate test of the Fascist experiment's 'totalitarian energies', as it indissolubly linked biological, political, historical and spiritual values in the building of the reborn community. ${ }^{61}$ Racism offered the illusion of collective and personal palingenesis, of attaining the ultimate unity of the nation, envisaged as a solid and dynamic entity whose task was the dissemination of the alleged universal principles of the Fascist revolution. ${ }^{62}$ Italians as a race were endowed with the qualities of dynamism, an inherent tendency to the universal and to the dominion of space, a mind perfectly attuned to modernity due to its supposed architectural and harmonious formation, all values that were making possible the 'renaissance of the domineering spirit of our people. 63 The racial policies were also intended as a furthering of the development of the self, in its quest for an alternative modernity, a qualitative process of differentiation where true Italians could be 'exclusively ourselves to become better than what we already are'.64

The integrity of the race was also necessary for the nationalisation and regeneration of the masses. Racial policies were often presented as the ultimate civilising process of modern times, as it anticipated a radical alteration of moral and social mores, both at the individual and collective level. ${ }^{65}$ It was about profoundly changing old customs and habits and furthering the character of the new Italian as history-maker. In this respect, the conquest of the Empire had accelerated Fascism's grandiose history-making drive. The Empire was, above all, a spiritual reality, 'a conquest that modifies the soul of the conquerors and which inaugurates a superior historical phase' in which there was no room for heterogeneous and 'parasitical' elements that could slow down Fascism's drive towards universality. ${ }^{66}$

For many Fascists, no other race had sublimated humanity as the Italian one, with its emperors, popes, saints, heroes, artists, warriors and scientists. More often than not, Fascists returned to a mythical past, particularly the Roman one. ${ }^{67}$ This did not entail a mere form of reactionary politics, or a pompous

61 'La politica della razza e I GUF,' Libro e Moschetto, 6 August 1938.

62 Aldo Vignolo, 'L'Essenza sociale del razzismo,' Libro e Moschetto, 8 October 1938.

63 Giovanni Marro, Caratteri fisici e spirituali della razza italiana (Rome: Istituto Nazionale di Cultura Fascista, 1939), 41.

64 Fontanelli, Sentimento, 89.

65 Emilio Giorgi, 'Fascismo: idea generatrice della vera rivoluzione spiritual del secolo xx,' Libro e Moschetto, 25 February 1939.

66 Giorgio Pini, 'Coscienza di razza', in Inchiesta sulla razza, ed. Paolo Orano (Rome: Pinciana, 1939), 231.

67 For the cult of Rome in Fascist Italy see, for example, Aristotle Kallis, The Third Rome, 1922-43: The Making of the Fascist Capital (Basingstoke: Palgrave Macmillan, 2014); Joshua 
and theatrical expression, but rather, the cult of Rome was used as a device for Fascism's broader project of refashioning Italy and Italians in their search for an alternative vision of modernity to the one provided by the Enlightenment. Giorgio Pini was eloquent about this crucial feature of Fascist ideology: 'the recourse ... to Rome and to the glorious traditions of the past cannot justify potential tendencies that reject modernity ... The Italian race anchors its roots in centuries and millennia of history, but its revival irresistibly projects it towards the future, in the most dynamic of modernities'. It was a leap forward that aimed at the 'creation of a new civilisation which will be ultra-modern, but healthy and ours'.68

\section{Conclusion}

However optimistic Mussolini and other Fascists may have been at times about the ultimate enactment of their anthropological revolution, towards the beginning of the Second World War many, starting with the Duce himself, realized that the effort was not going according to plan. In their minds, too many centuries of foreign domination remained. For Mussolini, the blame was to be put on the doorsteps of the Italian themselves and their flawed national character, which the Fascist ventennio had been unable to remedy. According to Galeazzo Ciano, on 29 January 1940, the Fascist leader bitterly commented on how 'the Italian race was a race of sheep' and that eighteen years in power had not been enough to transform it into a race of warlike men and masters of history. With the disastrous military defeats that ensued during the Second World War, the effort of creating new and martial men seemed ever more aloof from reality.

The endeavour of creating a new, modern man and civilisation certainly failed, like all the other totalitarian experiments espoused by the regime. Nevertheless, it would be too easy to dismiss it simply as an empty slogan or cheap propaganda. Fascism's quest in creating the New Man offers exciting avenues of research for the exploration of utopia within Fascist ideology as well as its historical imaginary and representation. Furthermore, the study of the anthropological revolution enables a better understanding of Fascism's totalitarian and revolutionary potential as well as its hubristic belief in creating a new and

Arthurs, Excavating Modernity. The Roman Past in Fascist Italy (Ithaca and London: Cornell University Press, 2012) and, Emilio Gentile, Fascismo di pietra (Rome and Bari: Laterza, 2008).

68 Giorgio Pini, 'Orgoglio di razza', in Inchiesta sulla razza, 236-237. 
alternative form of modernity. Particularly important is the fact that this political myth can permit to better grasp the radicalising momentum that the regime acquired during the 1930s, as manifested in the anti-bourgeoisie and racist campaigns. Indeed, as one of the most repressive regimes of the twentieth century, the myth of the New Man should make us re-consider the place exercised by violence during the Fascist rule, in the sense that it was far more extended and intensive than is usually thought. ${ }^{69}$ Additionally, the myth of the New Man allows us to further understand key concepts and relationships of modern ideologies, such as power, liberty, the relationship between leaders and led, authority and freedom, the state and the individual, the nationalisation of the masses and the New Man as an instrument of collective action to realize the latter aim.

69 For this aspect see Michael Ebner, Ordinary Violence in Mussolini's Italy (Cambridge: Cambridge University Press, 2011). 